EWA MARIA WŁODYKA

Politechnika Koszalińska

DOI : $10.14746 /$ rie.2021.15.22

ORCID: 0000-0002-8229-342X

\title{
Wpływ pandemii SARS-CoV-2 na strategię rozwoju lokalnego kierowanego przez społeczność
}

Z funduszy unijnych, rozumianych jako środki finansowe wykorzystywane w celu wspierania i restrukturyzacji gospodarek krajów członkowskich Unii Europejskiej, pochodzą środki przeznaczone na realizację Programów Operacyjnych ${ }^{1}$ dla poszczególnych regionów krajów członkowskich Unii Europejskiej. W Rzeczpospolitej Polskiej programy operacyjne oparte zostały o klasyfikację NUTS ${ }^{2}$ - w takim wypadku to województwa są odpowiedzialne za ostateczne osiągnięcie celów w zawartych w regionalnych programach operacyjnych, które określają sposób wykorzystania środków z europejskich funduszy strukturalnych i inwestycyjnych w okresie programowania ${ }^{3}$. Warunkowość realizacji planów finansowych celów uzależniona jest od osiągnięcia wyznaczonych m.in. w lokalnej strategii rozwoju wskaźników. Sytuacja ta zmieniła

${ }^{1}$ Programy są dokumentami o charakterze operacyjno-wdrożeniowym ustanawianymi w celu realizacji strategii rozwoju, określającymi działania przewidziane do realizacji zgodnie z ustalonym systemem realizacji programu i planem finansowym, stanowiącymi element programu. Programy przyjmuje się w drodze uchwały lub decyzji odpowiedniego organu - ustawa z dnia 6 grudnia $2006 \mathrm{r}$. o zasadach prowadzenia polityki rozwoju, Dz. U. 2006, Nr 227, poz. 1658, art. 15, ust. 1.

${ }^{2}$ Klasyfikacja Jednostek Terytorialnych do Celów Statystycznych - w skrócie NUTS (z francuskiego: Nomenclature des Unités territoriales statistiques; angielski: Classification of Territorial Units for Statistics, nazywana także Nomenclature of Territorial Units for Statistics) jest standardem geograficznym służącym do statystycznego podziału państw członkowskich Unii Europejskiej (ich terytoriów gospodarczych) na trzy poziomy regionalne o określonych klasach liczby ludności. Została ona ustanowiona w celu zbierania, opracowania i rozpowszechniania na obszarze Unii Europejskiej porównywalnych danych dla określonych statystyk regionalnych (np. z zakresu rachunków regionalnych, demografii, rynku pracy i społeczeństwa informacyjnego). Klasyfikacja NUTS służy również kształtowaniu regionalnych polityk krajów Unii Europejskiej i jest niezbędna do przeprowadzania analiz stopnia rozwoju społeczno-gospodarczego regionów. Wprowadzona została rozporządzeniem Parlamentu Europejskiego i Rady z dnia 26 maja 2003 r. (Rozporządzenie (WE) nr 1059/2003 Parlamentu Europejskiego i Rady z dnia 26 maja 2003 roku w sprawie ustalenia wspólnej klasyfikacji Jednostek Terytorialnych do Celów Statystycznych (NUTS), Dz. Urz. UE L 154 z 21.06.2003), a weszła w życie 11 lipca 2003 r. zastępując wcześniejszą „Nomenklaturę Jednostek Terytorialnych do Celów Statystycznych (NUTS)" ustalaną doraźnie przez Eurostat we współpracy z krajowymi urzędami statystycznymi. Za: Klasyfikacja NUTS, Główny Urząd Statystyczny, https:// stat.gov.pl/statystyka-regionalna/jednostki-terytorialne/klasyfikacja-nuts/, 1.10.2021.

${ }^{3} \mathrm{~W}$ zakresie rozwoju lokalnego kierowanego przez społeczność, określone w ustawie zadania zarząd województwa wykonuje jako: instytucja zarządzająca, organ reprezentujący: instytucję pośredniczącą właściwą w zakresie rozwoju lokalnego kierowanego przez społeczność lub podmiot wdrażający właściwy do przyznawania pomocy w ramach działania „Wsparcie dla rozwoju lokalnego w ramach inicjatywy LEADER". Na podstawie: ustawa $z$ dnia 20 lutego 2015 r. o rozwoju lokalnym z udziałem lokalnej społeczności, Dz. U. 2015, poz. 378. 
się od momentu wybuchu światowej epidemii, która uniemożliwiła w wielu przypadkach zachowanie zakładanego przez beneficjentów wypełnienia pierwotnych lokalnych kryteriów. Kryteria te, podobnie jak sama strategia lokalnego rozwoju, są indywidualne i charakterystyczne w kontekście zróżnicowania regionalnego dla każdego z województw w kraju. Ze względu na zainteresowanie obszarem badawczym, jakim jest województwo zachodniopomorskie, na jego przykładzie przeanalizowałam wnioski, jakie wpłynęły do Stowarzyszenia Środkowopomorska Grupa Działania (ŚGD) w okresie od 2020 do 2021 roku. ŚGD, będąca partnerstwem trójsektorowym (w skład którego wchodzą podmioty sektora publicznego, społecznego, gospodarczego i mieszkańcy), jest największą z dwunastu lokalnych grup działania ${ }^{4}$ w województwie zachodniopomorskim i jednocześnie jedną z największych w Polsce. Ponadto, opracowana przez nią Lokalna Strategia Rozwoju na lata 2014-2020, która została złożona w konkursie ogłoszonym przez Zarząd Województwa Zachodniopomorskiego, uzyskała $98 \%$ możliwych do zdobycia punktów ${ }^{5}$. Jest to argumentacja dla autorki wystarczająca do uznania ŚGD jako reprezentatywnej w omawianym badaniu dla lokalnych grup działania z obszaru województwa zachodniopomorskiego.

Wykorzystałam techniki badawcze adekwatne do przedmiotu i charakterystyki badań. Przy weryfikacji tezy badawczej posłużono się poniższymi, adekwatnymi dla nauk o polityce i administracji metodami badawczymi: metodą porównawczą, metodą opisową i przede wszystkim analizą dokumentów. Przyjęta metodologia badań z wykorzystaniem materiału teoretycznego i empirycznego, przy uwzględnieniu doktryny i orzecznictwa, pozwoliła na zaproponowanie prognoz i postawienie wniosków odpowiadających na pytania o wpływ pandemii Sars-Cov-2 na realizację wskaźników tworzonych we współudziale społeczności, kierująca co do założeń rozwojem lokalnym. Do hipotezy o negatywnym wpływie pandemii na realizację wymaganych do realizacji lokalnej strategii rozwoju wskaźników postawiłam pytania badawcze o charakter wnioskowanych przez beneficjentów zmian.

Publikacja nie wyczerpuje wszystkich poruszonych kwestii, niemniej jednak może być przyczynkiem do dalszej dyskusji nad postawioną tezą. Pokazuje, jak aktualny jest to temat. Brakuje w tym obszarze najnowszych opracowań naukowych o charakterze interdyscyplinarnym w połączeniu $\mathrm{z}$ chociażby naukami ekonomicznymi.

\section{Kontekst normatywny}

Rozwój lokalny kierowany przez społeczność (RLKS) ${ }^{6}$ jest nowym instrumentem terytorialnym, wprowadzonym przez Komisję Europejską w perspektywie fi-

${ }^{4}$ Zasady organizacji i działania lokalnych grup działania określa ustawa $z$ dnia 20 lutego $2015 \mathrm{r}$. o rozwoju lokalnym..., 2015.

${ }^{5}$ Z Samorządu Województwa Zachodniopomorskiego na realizację strategii rozwoju lokalnego kierowanego przez społeczność w ramach Programu Rozwoju Obszarów Wiejskich na lata 20142020 pozyskano $15 \mathrm{mln}$ złotych, których cel przeznaczenia to: lokalne inicjatywy, nowe miejsca pracy, rozwój gospodarczy, inwestycje w infrastrukturę turystyczną i rekreacyjną na terenie gmin wchodzących w skład Stowarzyszenia ŚGD - obszar piętnastu jednostek samorządu terytorialnego. Na podstawie: Stowarzyszenie, https://stowarzyszeniesgd.pl/stowarzyszenie, 1.09.1921.

${ }^{6}$ Ang. Community led-local development (CLLD). 
nansowej lat 2014-2020. Instrument ten bazuje na stosowanym w latach 2007-2013 w ramach Wspólnej Polityki Rolnej i Wspólnej Polityki Rybołówstwa podejściu LEADER, zachowując jego podstawowe założenia ${ }^{7}$. Umożliwia zastosowanie metody LEADER także $\mathrm{w}$ ramach polityki spójności w ramach wspólnej podstawy prawnej, czyli art. 32-35 rozporządzenia Parlamentu Europejskiego i Rady (UE) nr 1303/2013 z dnia 17 grudnia 2013 r. (Rozporządzenie Rady (WE) nr 1083/2006, 2006, s. 320) ${ }^{8}$. Pełny wyraz wykorzystania instrumentu RLKS w realizacji polityk unijnych odnaleźć można w Umowie Partnerstwa (Umowa Partnerstwa, 2020) ${ }^{9}$ oraz ustawie o rozwoju lokalnym z udziałem lokalnej społeczności (Ustawa z dnia 20 lutego 2015 r. o rozwoju lokalnym..., 2015). Ustawa ta nadała podstawy prawne do tworzenia lokalnych strategii rozwoju i wydatkowania środków publicznych ze szczególnym uwzględnieniem w stosunku do wcześniejszych działań partycypacyjnego sposobu redystrybucji środków finansowych. Oddolne planowanie w planowaniu i realizacji działań miało znaczenie kluczowe.

Zgodnie $\mathrm{z}$ przepisami rozporządzenia ramowego RLKS jest (Rozporządzenie Rady (WE) nr 1083/2006, 2006, art. 32 (2)): a) skoncentrowany na konkretnych obszarach poniżej szczebla regionalnego; b) kierowany przez lokalne grupy działania, w których skład wchodzą przedstawiciele władz publicznych, lokalnych partnerów społecznych i gospodarczych oraz mieszkańców, przy czym na poziomie podejmowania decyzji ani władze publiczne - określone zgodnie z przepisami krajowymi

${ }^{7}$ RLKS zachowuje podstawowe założenia metody LEADER, to jest: a) oddolność (szeroki udział społeczności lokalnej w tworzeniu i realizacji strategii), b) terytorialność (lokalna strategia rozwoju przygotowana dla danego, spójnego obszaru), c) zintegrowanie (łączenie różnych dziedzin gospodarki, współpraca różnych grup interesu), d) partnerstwo (lokalna grupa działania jako lokalne partnerstwo, w którym uczestniczą różne podmioty z sektora publicznego, społecznego i gospodarczego), e) innowacyjność (w skali lokalnej), f) decentralizacja zarządzania i finansowania, g) sieciowanie i współpraca (wymiana doświadczeń i rozpowszechnianie dobrych praktyk). Na podstawie: Zasady realizacji instrumentu „, Rozwój lokalny kierowany przez społeczność w Polsce”, Ministerstwo Infrastruktury i Rozwoju, Warszawa 2014, http://www.rpo.wzp.pl/sites/ default/files/zasady_realizacji_rlks_02042014.pdf, 1.10.2021, s. 3. Przed 2014 rokiem LEADER był narzędziem stosowanym w perspektywie finansowej Unii Europejskiej 2007-2013 w ramach: II filara wspólnej polityki rolnej jako „podejście LEADER”, czyli obowiązkowa oś 4 Leader programów rozwoju obszarów wiejskich współfinansowanych z EFRROW oraz wspólnej polityki rybołówstwa jako „zrównoważony rozwój obszarów zależnych głównie od rybactwa”, w ramach osi priorytetowej 4 programów operacyjnych współfinansowanych ze środków Europejskiego Funduszu Rybackiego.

${ }^{8}$ Rozporządzenie to ustanawia wspólne przepisy dotyczące Europejskiego Funduszu Rozwoju Regionalnego, Europejskiego Funduszu Społecznego, Funduszu Spójności, Europejskiego Funduszu Rolnego na rzecz Rozwoju Obszarów Wiejskich oraz Europejskiego Funduszu Morskiego i Rybackiego oraz ustanawiającego przepisy ogólne dotyczące Europejskiego Funduszu Rozwoju Regionalnego, Europejskiego Funduszu Społecznego, Funduszu Spójności i Europejskiego Funduszu Morskiego i Rybackiego oraz uchylającego rozporządzenie Rady (WE) nr 1083/2006. Na podstawie: Rozwój Lokalny Kierowany przez Spoleczność (RLKS), Ministerstwo Rolnictwa i Rozwoju Wsi, https://www.gov.pl/web/rolnictwo/rozwoj-lokalny-kierowany-przez-spolecznosc-rlks, 1.10.2021.

${ }^{9}$ Umowa Partnerstwa jest dokumentem określającym kierunki interwencji w latach 2014-2020 trzech polityk unijnych w Polsce - Polityki Spójności, Wspólnej Polityki Rolnej i Wspólnej Polityki Rybołówstwa. 
- ani żadna z grup interesu nie posiada więcej niż 49\% praw głosu; c) prowadzony na podstawie zintegrowanych i wielosektorowych lokalnych strategii rozwoju; d) zaprojektowany z uwzględnieniem lokalnych potrzeb i potencjału oraz zawiera elementy innowacyjne w kontekście lokalnym i zakłada tworzenie sieci kontaktów oraz, w stosownych przypadkach, współpracę. Stąd wiadomo, że i sami beneficjenci działań lokalnych grup działania mogą współuczestniczyć w budowie lokalnych strategii rozwoju z uwzględnieniem potencjału społeczności lokalnej. Podobnie wskazuje na współuczestnictwo międzysektorowe na etapie tworzenia wytycznych do realizacji lokalnej strategii ŚGD ${ }^{10}$. Cele i przedsięwzięcia ŚGD odpowiadają zjawiskom zidentyfikowanym w Lokalnej Strategii Rozwoju - w diagnozie i analizie SWOT oraz kluczowym obszarom interwencji i kluczowym grupom docelowym (LSR 2014-2020, Cele i przedsięwzięcia, 2016) oraz Regionalnego Programu Operacyjnego Województwa Zachodniopomorskiego na okres 2014-2020 (RPO WZ 2014-2020) ${ }^{11}$.

\section{Kontekst regionalny}

Dzięki partycypacyjnej metodzie planowania tychże polityk i wykorzystaniu narzędzi rozwoju lokalnego kierowanego przez społeczność dotychczasowe realizacje wyznaczone w lokalnych strategiach ŚGD nie pozostawały zagrożone. Jednakże paraliż organizacyjny wywołany ograniczeniami związanymi z bezpieczeństwem w czasie pandemii dotyczył wielu podmiotów życia społeczno-gospodarczego na obszarze wielu państw. Powiązania globalizacyjne wpłynęły w nie mniejszym stopniu na trudności pojawiające się wśród profitentów ŚGD niż uwarunkowania lokalne. W związku z powyższym, do biura ŚGD zaczęli się zwracać beneficjenci z prośbą o wyrażenie zgody na zmianę poszczególnych warunków umów ${ }^{12}$ zawartych z Zarządem Województwa Zachodniopomorskiego. Warunki te miały różnorodny charakter:

10 „Społeczność lokalna składająca się z przedstawicieli trzech sektorów i mieszkańców brała udział w formułowaniu potrzeb i problemów obszaru SŚGD znajdujących odzwierciedlenie w przygotowanej diagnozie obszaru, jak również na etapie formułowania celów i ustalania ich hierarchii, poszukiwania rozwiązań stanowiących sposoby ich realizacji, tworzenia wskaźników i identyfikacji grup docelowych." - źródło: LSR 2014-2020, 2016, https://stowarzyszeniesgd.pl/dla-beneficjenta, 1.10.2021.

${ }^{11}$ RPO WZ 2014-2020 w sposób istotny przyczyni się do realizacji strategii Europa 2020 z uwagi na zaplanowaną szeroką interwencję w ramach jej trzech kluczowych priorytetów: „Rozwój inteligentny - rozwój gospodarki opartej na wiedzy i innowacji”, „Rozwój zrównoważony - wspieranie gospodarki efektywniej korzystającej z zasobów", rozwój sprzyjający włączeniu społecznemu - wspieranie gospodarki charakteryzującej się wysokim poziomem zatrudnienia i zapewniającej spójność gospodarczą, społeczną i terytorialną. Za: Regionalny Program Operacyjny Województwa Zachodniopomorskiego na okres 2014-2020 (RPO WZ 2014-2020), Szczecin 2015, s. $6-9$.

${ }^{12}$ Umowy określają prawa i obowiązki stron związane z realizacją operacji w ramach poddziałania „Wsparcie na wdrażanie operacji w ramach działania Wsparcie dla rozwoju lokalnego w ramach inicjatywy LEADER" objętego Programem w zakresie przedmiotowym. 
Wybrane wnioskowane przez beneficjentów zmiany wskaźników realizacji Lokalnej Strategii Rozwoju

\begin{tabular}{|c|c|c|c|c|c|c|}
\hline L.p. & $\begin{array}{c}\text { Rok } \\
\text { zawarcia } \\
\text { umowy }\end{array}$ & $\begin{array}{l}\text { Rok wniosku } \\
\text { o zmianę } \\
\text { warunków } \\
\text { umowy }\end{array}$ & Branża & $\begin{array}{c}\text { Wnioskowana zmiana } \\
\text { wskażnika }\end{array}$ & $\begin{array}{c}\text { Rodzaj } \\
\text { operacji }\end{array}$ & Sektor \\
\hline 1. & 2019 & 2020 & $\begin{array}{c}\text { gastro- } \\
\text { nomicz- } \\
\text { na }\end{array}$ & $\begin{array}{l}\text { „liczba utworzonych miejsc pra- } \\
\text { cy” i „liczba utrzymanych miejsc } \\
\text { pracy” z } 2,5 \text { pełnego etatu śred- } \\
\text { niorocznego na } 1,5 \text { pełnego etatu } \\
\text { średniorocznego }\end{array}$ & $\begin{array}{l}\text { rozwój przed- } \\
\text { siębiorstw }\end{array}$ & $\begin{array}{l}\text { gospo- } \\
\text { darczy }\end{array}$ \\
\hline 2. & 2018 & 2020 & $\begin{array}{l}\text { gastro- } \\
\text { nomicz- } \\
\text { na }\end{array}$ & $\begin{array}{l}\text { „liczba utworzonych miejsc pra- } \\
\text { cy” z } 1,5 \text { pełnego etatu średnio- } \\
\text { rocznego na } 1,00 \text { pełnego etatu } \\
\text { średniorocznego. }\end{array}$ & $\begin{array}{l}\text { rozwój przed- } \\
\text { siębiorstw }\end{array}$ & $\begin{array}{l}\text { gospo- } \\
\text { darczy }\end{array}$ \\
\hline 3. & 2020 & 2021 & $\begin{array}{l}\text { hotelar- } \\
\text { ska }\end{array}$ & przesunięcie płatności końcowej & $\begin{array}{l}\text { rozwój przed- } \\
\text { siębiorstw }\end{array}$ & $\begin{array}{l}\text { gospo- } \\
\text { darczy }\end{array}$ \\
\hline
\end{tabular}

Źródło: Opracowanie własne.

Potwierdzające z punktu widzenia postawionej hipotezy wydają się być argumenty poszczególnych wnioskodawców podające jako powód wnioskowanej zmiany pandemię Sars-Cov-2, a jako problemy i zagrożenia z nią związane:

- „brak możliwości świadczenia usług i likwidacja przedsiębiorstwa”,

- „dramatyczny spadek przychodów w analogicznym okresie roku poprzedniego",

- „zostaliśmy pozbawieni możliwości jakichkolwiek wpływów z posiadanych miejsc noclegowych"13.

Co charakterystyczne, mimo wybiórczego przedstawienia w zestawieniu wnioskowanych zmian wskaźników, we wszystkich pozostałych przypadkach nie pojawili się beneficjenci z dwóch pozostałych sektorów trójpartnerstwa w ramach SGD: sektora pozarządowego ani sektora samorządowego. Wskazuje to na realizację wskazanych przez nie we wniosku wskaźników mimo ograniczeń wynikających z pandemii.

Wszystkie, nie tylko ukazane $\mathrm{w}$ zestawieniu zbadane $\mathrm{w}$ danym okresie zmiany dotyczyły tych samych w ramach lokalnej strategii rozwoju następujących celów: cel ogólny $\mathrm{nr} 1$ Wsparcie rozwoju gospodarczego i konkurencyjności obszaru LSR do 2023 r., cel szczegółowy: 1.1 Rozwój przedsiębiorczości na obszarze LSR do 2023 roku, Przedsięwzięcie 1.1.1. Zakładanie działalności gospodarczej oraz Przedsięwzięcie 1.1.2. Rozwój przedsiębiorstw.

Zaobserwowano brak wniosków o zmianę wartości wskaźnika czy innego rodzaju warunków umowy na realizację zadania z sektora samorządowego i trzeciego sektora (w rozumieniu organizacji pozarządowych oraz inicjatyw społecznych mieszkańców) w ramach realizacji celów ogólnych nr 2 i 3.

${ }^{13}$ Cytaty pochodzą z wniosków beneficjentów o zmianę wskaźników lokalnej strategii rozwoju zawartych w umowach z Zarządem Województwa Zachodniopomorskiego. 
Tabela 2

Cele i przedsięwzięcia realizowane przez Stowarzyszenie Środkowopomorska Grupa Działania poprzez RLKS w okresie programowania 2014-2020

\begin{tabular}{|c|c|c|}
\hline \multirow[b]{2}{*}{$\begin{array}{l}\text { Cele ogólne } \\
\text { Cel ogólny I: } \\
\text { Wsparcie rozwoju gospo- } \\
\text { darczego i konkurencyjno- } \\
\text { ści obszaru LSR do } 2023 \mathrm{r} \text {. }\end{array}$} & \multirow{2}{*}{\begin{tabular}{l}
\multicolumn{1}{c}{ Cele szczególowe } \\
Cel szczegółowy: \\
1.1. Rozwój przedsiębiorczości \\
na obszarze LSR do $2023 \mathrm{r}$.
\end{tabular}} & Przedsięwzięcia \\
\hline & & \begin{tabular}{|l|} 
Przedsięwzięcie 1.1.1. \\
Zakładanie działalności gospodarczej \\
Przedsięwzięcie 1.1.2. \\
Rozwój przedsiębiorstw \\
\end{tabular} \\
\hline \multirow[t]{2}{*}{$\begin{array}{l}\text { Cel ogólny II. } \\
\text { Wzmocnienie atrakcyjności } \\
\text { obszaru LSR do } 2023 \mathrm{r} \text {. }\end{array}$} & $\begin{array}{l}\text { Cel szczegółowy: } \\
\text { 2.1. Budowa, przebudowa infra- } \\
\text { struktury turystycznej i rekreacyj- } \\
\text { nej na obszarze LSR do } 2023 \mathrm{r} \text {. } \\
\end{array}$ & $\begin{array}{l}\text { Przedsięwzięcie } 2.1 .1 . \\
\text { Infrastruktura turystyczna i rekreacyjna }\end{array}$ \\
\hline & $\begin{array}{l}\text { Cel szczegółowy: } \\
\text { 2.2. Promocja zasobów lokal- } \\
\text { nych obszaru LSR do } 2023 \text { r. }\end{array}$ & $\begin{array}{l}\text { Przedsięwzięcie 2.2.1. } \\
\text { Działania informacyjno-promocyjne }\end{array}$ \\
\hline $\begin{array}{l}\text { Cel ogólny III. } \\
\text { Aktywizacja mieszkańców } \\
\text { obszaru LSR i wzmocnie- } \\
\text { nie kapitału społecznego do } \\
2023 \text { r. }\end{array}$ & $\begin{array}{l}\text { Cel szczegółowy: } \\
\text { 3.1. Aktywizacja i integracja } \\
\text { mieszkańców obszaru LSR do } \\
2023 \text { r. }\end{array}$ & \begin{tabular}{|l|} 
Przedsięwzięcie 3.1.2. \\
Funkcjonowanie LGD \\
Przedsięwzięcie 3.1.3. \\
Projekty współpracy
\end{tabular} \\
\hline
\end{tabular}

Źródło: Cele i przedsięwzięcia, Stowarzyszenie Środkowopomorska Grupa Działania, https://stowarzyszeniesgd.pl/dla-beneficjenta, 1.10.2021.

Pozostałe wnioski również dotyczyły braku możliwości zachowania zakładanych wskaźników w branży przede wszystkim gastronomicznej, znacznie rzadziej hotelarskiej, najrzadziej - innych branż, które uzyskały dofinansowanie na rozwój przedsiębiorstw i zakładanie działalności gospodarczej ${ }^{14}$.

Każdy z wnioskodawców, zakładając powodzenie składanej prośby, zakładał brak wpływu proponowanej przez siebie zmiany na realizację celu ogólnego oraz celu szczegółowego. Jak wynika z analizy dokumentów, ocena wpływu zmiany umowy dokonywana przez Radę Oceniającą Stowarzyszenia Środkowopomorska Grupa Działania dotyczyła oceny zgodności operacji z LSR oraz lokalnymi kryteriami wyboru stosowanymi przy wyborze operacji do dofinansowania ${ }^{15}$. W swojej ocenie Rada Oceniająca ŚGD jednak samodzielnie analizowała wpływ proponowanej zmiany na realizację celu ogólnego oraz celu szczegółowego. Wykazywała we wszystkich przypadkach, czy na dzień wydania opinii zmiana planowa przez beneficjenta nie stanowi zagrożenia dla realizacji wspomnianych celów (głównego i szczegółowego), a realizacja operacji przy uwzględnieniu zmniejszonego wymiaru zatrudnienia wciąz pozwoli lokalnej grupie działania na osiagnięcie wskaźników zaplanowanych w Lokalnej Strategii Rozwoju na lata $2014-2020^{16}$. Zmiany umowy o przyznaniu pomocy moty-

14 Rozkład wydatkowania środków na poszczególne branże przedstawiony został w: Stopień wdrażania Lokalnej Strategii Rozwoju na lata 2014-2020. Materiaty szkoleniowe Luboradza, 1 października $2021 \mathrm{r}$.

${ }^{15}$ Zgodnie z obowiązującymi przepisami przez operację zgodną z LSR rozumie się operację, która m.in. zakłada realizację celów głównych i szczegółowych LSR, przez osiąganie zaplanowanych w LSR wskaźników.

${ }^{16}$ Uchwała nr VII/1/21 Rady Oceniającej Stowarzyszenia Środkowopomorska Grupa Działania $z$ dnia 10 czerwca $2021 \mathrm{r}$. 
wowano m.in. skutkami nadzwyczajnych okoliczności będących wynikiem pandemii COVID-19.

\section{Zakończenie}

Pandemia wirusa Sars-CoV-2 bez wątpienia utrudniła - a raczej właściwym będzie stwierdzenie wciąż utrudnia - wypełnienie wskaźników określających realizację polityk strukturalnych wskazanych w Regionalnym Programie Operacyjnym Województwa Zachodniopomorskiego na okres 2014-2020 oraz Lokalnej Strategii Rozwoju Stowarzyszenia Środkowopomorskiej Grupy Działania. Mimo faktu, iż każdy z trzech podmiotów przedstawianego partnerstwa trójsektorowego jest elementem rozwoju lokalnego kierowanego przez społeczność jako nowego instrumentu terytorialnego, to nie każdy z trzech podmiotów miał tak duży jak sektor gospodarczy problem z realizacją zakładanych wskaźników. Problem ten dotyczył przede wszystkim podmiotów realizujących cel szczegółowy lokalnej strategii rozwoju: rozwój przedsiębiorstw. W przypadku braku zmiany osiągnięcia zawartych w umowie z Zarządem Województwa Zachodniopomorskiego efektów, beneficjentom tym groziła upadłość. Interesującym z punktu widzenia nauk społecznych wydaje się być pytanie afirmujące ewentualne kolejne badania o powiązanie takowych podmiotów $\mathrm{z}$ ich aktywnością $\mathrm{w}$ procesie partycypowania $\mathrm{w}$ stanowieniu zapisów lokalnej strategii rozwoju ŚGD. Pytaniem kolejnym - czy jedynie przypadkiem jest zbieżność obecności aktywności pozostałych podmiotów realizujących RLKS (jednostek samorządu terytorialnego i podmiotów społecznych) i brakiem tak znacznej natury przeszkód w realizacji podejmowanych przez nie działań w okresie pandemii ${ }^{17}$ ? Czy też charakter tych podmiotów pozwala na innych rodzaj napotykanych problemów niż te, które dotyczyły sektora gospodarczego? Faktem jest, że oba pozostałe sektory (obok partnera gospodarczego) znacznie częściej niż sektor biznesu wykorzystują RLKS na poziomie tworzenia polityk, przez zgłaszanie uwag i wniosków do tworzonych lokalnych strategii rozwoju - przez co być może trafniej dobrane są pod tym względem omawiane wskaźniki.

\section{Bibliografia}

Cele i przedsięwzięcia, Stowarzyszenie Środkowopomorska Grupa Działania, https://stowarzyszeniesgd.pl/dla-beneficjenta, 1.10.2021.

Klasyfikacja NUTS, Główny Urząd Statystyczny, https://stat.gov.pl/statystyka-regionalna/jednostki-terytorialne/klasyfikacja-nuts/, 1.10.2021.

LSR 2014-2020 (2016), https://stowarzyszeniesgd.pl/dla-beneficjenta, 1.10.2021.

Regionalny Program Operacyjny Województwa Zachodniopomorskiego na okres 2014-2020 (RPO WZ 2014-2020) (2015), Szczecin.

Rozporządzenie (WE) nr 1059/2003 Parlamentu Europejskiego i Rady z dnia 26 maja 2003 roku w sprawie ustalenia wspólnej klasyfikacji Jednostek Terytorialnych do Celów Statystycznych (NUTS), Dz. Urz. UE L 154 z 21.06.2003 r.

Rozporządzenie Rady (WE) nr 1083/2006, Dz. Urz. UE L 347 z 20.12.2013 r.

${ }^{17}$ Wniosek na podstawie analizy dokumentów. 
Stopień wdrażania Lokalnej Strategii Rozwoju na lata 2014-2020. Materiały szkoleniowe, Luboradza, 1 października $2021 \mathrm{r}$.

Stowarzyszenie, https://stowarzyszeniesgd.pl/stowarzyszenie, 1.09.1021.

Uchwała nr VII/1/21 Rady Oceniajacej Stowarzyszenia Środkowopomorska Grupa Działania z dnia 10 czerwca $2021 \mathrm{r}$.

Umowa Partnerstwa, 11.03.2020, https://www.funduszeeuropejskie.gov.pl/strony/o-funduszach/dokumenty/umowa-partnerstwa/, 1.10.2021.

Ustawa z dnia 20 lutego 2015 r. o rozwoju lokalnym z udziatem lokalnej społeczności, Dz. U. 2015, poz. 378.

Ustawa z dnia 6 grudnia 2006 r. o zasadach prowadzenia polityki rozwoju, Dz. U. 2006, Nr 227, poz. 1658.

Zasady realizacji instrumentu „Rozwój lokalny kierowany przez społeczność w Polsce”, Ministerstwo Infrastruktury i Rozwoju, Warszawa 2014, http://www.rpo.wzp.p1/sites/default/files/ zasady_realizacji_rlks_02042014.pdf, 1.10.2021.

\section{Streszczenie}

Pandemia wirusa SARS-CoV-2 udowodniła, że dotychczasowe schematy funkcjonowania funduszy unijnych ${ }^{18}$ nie zawsze sprawdzają się w nowej rzeczywistości społeczno-gospodarczej. Takim wadliwym, uniemożliwiającym zgodne z pierwotnymi założeniami realizacji lokalnej strategii rozwoju elementem okazały się wnioski beneficjentów o możliwości zmiany umowy o przyznanie pomocy. Wnioski te dotyczyły umów zawieranych poprzez lokalne grupy działania z województwem, które odpowiada za realizację programu operacyjnego i zagrażały zachowaniu realizacji wszystkich priorytetów. Główna hipoteza badawcza opiera się na założeniu, że pandemia wpłynęła negatywnie na realizację wymaganych do realizacji lokalnej strategii rozwoju wskaźników.

Slowa kluczowe: pandemia SARS-CoV-2, fundusze strukturalne, lokalne grupy działania

\section{The impact of the SARS-CoV-2 pandemic on the community-led local development strategy}

\section{Summary}

The SARS-CoV-2 pandemic has proven that the existing schemes for the operation of EU funds do not always work in the new socio-economic reality. Such a defective element, making it impossible to implement a local development strategy in accordance with the original assumptions, turned out to be the beneficiaries' requests for the possibility of amending the contract for granting aid. These requests related to agreements concluded by Local Action Groups with the voivodship which is responsible for the implementation of the operational programme and threatened the preservation of the implementation of all priorities. The main research hypothesis is based on the assumption that the pandemic had a negative impact on the implementation of indicators required to implement the local development strategy.

Key words: SARS-CoV-2 pandemic, structural funds, local action groups

${ }^{18}$ Rozumianych jako środki finansowe wykorzystywane w celu wspierania i restrukturyzacji gospodarek krajów członkowskich Unii Europejskiej. 